\title{
Sistem Pendukung Keputusan Pengajuan dan Penilaian Beasiswa Berbasis Website Menggunakan Metode TOPSIS
}

\author{
Malik Ibrahim \\ Teknik Informatika, Universitas PGRI Madiun, Indonesia \\ Email: masmalikibrahim@gmail.com
}

\begin{abstract}
Abstrak
Setiap perguruan tinggi khususnya Universitas memiliki banyak sekali program kerja yang ditawarkan bagi mahasiswa, salah satunya adalah beasiswa. Universitas PGRI Madiun (UNIPMA) juga menyediakan beasiswa bagi mahasiswanya, namun dalam proses pemberian beasiswa masih mengalami kendala dalam proses penghitungan penilaian beasiswa yaitu membutuhkan waktu lama dan masih menggunakan aplikasi sederhana dengan bantuan software microsoft excel. Tentunya, hal ini akan menghambat waktu dalam proses kecepatan pengolahan nilai penerimaan beasiswa.Beasiswa ini memiliki beberapa syarat dan kriteria untuk dinilai maka diperlukan suatu sistem yang mampu memutuskan dengan objektif. Metode penghitungan dan memecahan masalah dalam penelitian ini adalah menggunakan metode fuzzy TOPSIS sedangkan pengembangan sistem menggunakan model pengembangan waterfall. Tahapan pertama adalah analisis kebutuhan, kemudian menentukan desain meliputi perancangan user interface, perancangan sistem basisdata, percancangan sistem flowchart, perancangan ERD dan perancangan DFD. Selanjutnya penulisan kode program, kemudian tahapan terakhir adalah pengujian, implementasi dan pemeliharaan sistem. Sistem ini akan membuat keputusan yang dihasilkan benar benar tepat sasaran sesuai untuk menjalankan proses penilaian dengan banyak kriteria sehingga dapat mempercepat dalam pengolahan penerima beasiswa harapan dengan adanya sistem ini dapat membantu Biro Akademik dan Kemahasiswaan selaku pengolah nilai beasiswa dalam menentukan penerima beasiswa dengan cepat, tepat dan optimal.
\end{abstract}

\section{Kata Kunci : Sistem Pendukung Keputusan, Beasiswa, Topsis, Waterfall}

\section{PENDAHULUAN}

Pendidikan formal merupakan salah satu faktor pendukung sumber daya manusia berkualitas. Melalui dunia pendidikan diharapkan kemampuan berpikir dan kecerdasan seseorang dapat dikembangkan agar mampu memanfaatkan dan mengolah sumber daya yang tersedia. Setiap perguruan tinggi khususnya universitas memiliki banyak sekali program kerja yang ditawarkan bagi mahasiswa, salah satunya adalah program beasiswa. Tujuan dari program beasiswa ini diadakan untuk meringankan beban mahasiswa selama menjalani masa studi khususnya masalah biaya. Universitas PGRI Madiun (UNIPMA) adalah salah satu perguruan tinggi swasta di kota madiun yang menyediakan program beasiswa bagi mahasiswa yang berprestasi maupun yang kurang mampu dalam biaya pendidikannya.
Proses pemberian biaya kuliah gratis di Universitas PGRI Madiun (UNIPMA) masih mengalami kendala dalam proses pengambilan keputusan untuk menentukan siapa saja mahasiswa yang berhak mendapatkan beasiswa karena proses penghitungan penilaian membutuh waktu lama mengingat banyak kriteria persyaratan yang memiliki bobot berbeda setiap jenis beasiswa yang ditetapkan universitas. Terlebih pada bagian Biro Kemahasiswaan dan Alumni (BKA) dalam penghitungannya masih menggunakan aplikasi sederhana yaitu menggunakan software microsoft excel untuk mengolah nilai data pengajuan beasiswa. Tentunya, hal ini akan menghambat waktu dalam proses kecepatan pengolahan nilai penerimaan beasiswa. Mengingat masing-masing beasiswa memiliki beberapa syarat dan kriteria untuk dinilai maka diperlukan suatu sistem yang mampu memutuskan 
dengan objektif. Sistem ini akan membuat keputusan yang dihasilkan benar benar tepat sasaran sesuai untuk menjalankan proses penilaian dengan banyak kriteria sehingga dapat mempercepat dalam pengolahan penerima beasiswa.

Permasalah tersebut memiliki relevansi dengan penelitian yang sama yaitu Arbian (2017) hasil dari penelitian tersebut adalah sistem ini dapat menyelesaikan pengambilan keputusan dengan beberapa kriteria yang akan menjadi bahan pertimbangan menggunakan Metode Algoritma TOPSIS untuk mendapatkan alternatif dengan nilai tertinggi dan untuk menentukan rangking penerima beasiswa berdasarkan kriteria-kriteria yang telah ditentukan. Herawatie dan Wuryanto (2017) dalam penelitianya menunjukan bahwa hasil dari penelitian tersbut adalah hasil yang disajikan berupa perhitungan dari angka sesuai kreiteria kemudian data di matrikan setelah itu data dinormalisasi kemudian data akan keluar dengan keterangan peringkat tujuan penelitian tersebut adalah mencari mahasiswa terbaik kemudian memberikan beasiswa pendidikan.

Berdasarkan uraian penelitian terdahulu, maka diketahui bahwa sistem pendukung keputusan menggunakan metode TOPSIS ini memiliki Gap Research menggunakan penelitian kedua yaitu Herawatie dan Wuryanto (2017) dimana perbedaan yang terlihat berada pada metode dalam penyajian visual antara penelitian yang dibangun yaitu berbasis website dengan penelitian yang relevan hanya sebatas penghitungan secara manual, penelitian kedua hanya membahasa bagaimana metode TOPSIS ini dapat memecahkan masalah dengan rumus perhitungan tanpa menampilkan hasil dalam bentuk visual (menggunakan bantuan teknologi).

\section{KAJIAN PUSTAKA}

\section{A. Sistem Pendukung Keputusan}

Nofriansyah dan Defit (2017) menyatakan bahwa sistem pendukung keputusan adalah suatu sistem informasi yang spesifik yang dituju unutk membantu manajemen dalam mengambil keputuusan yang berkaitan dengan persoalan yang bersifat semi terstrukur. Lebih lanjut Sari (2018) menyatakan bahwa pada dasarnya sistem pendukung keputusan ini atau dikenal juga dengan istilah Decision Support System (DSS). Ini merupakan pengembangan lebih lanjut dari sistem informasi manajemen terkomputerisasi yang dirancang sedemikian rupa sehingga bersifat interaktif dengan pemakaianya.

\section{B. Kecerdasan Buatan}

Wijayanti dan Fadlil (2014) menyatakan bahwa salah satu bagian dari sebuah ilmu komputer yang dapat diperintah dan bekerja sesuai kemampuan manusia disebut kecerdasan buatan. Pendapat lain menyatakan bahwa kecerdasan buatan (Artificial Intelligence) adalah kecerdasan manusia yang diterapkan pada sebuah mesin atau komputer yang bertujuan dapat melakukan kegiatan seperti manusia yang telah diprogram sebelumnya seperti permainan logika fuzzy, jaringan syaraf tiruan dan sistem pakar Mujilahwati (2014).

\section{Metode TOPSIS}

Sari (2018) menyatakan bahwa metode TOPSIS adalah metode yang menggunakana prinsip penghitungan berdasarkan alternatif yang terpilih mempunyai jarak dari solusi ideal positif dan terjauh dari solusi ideal negatif dari sudut pandangan geometris dengan menggunakan jarak euclidean untuk menentukan kedekatan relatif dari suatu alternatif dengan solusi optimal. TOPSIS akan merangking alternatif berdasarkan prioritas nilai kedekatan relatif suatu alternatif terhadap solusi ideal positif. Alternatif-alternatif yang telah dirangking kemudian dijadikan sebagai referensi bagi pengambil keputusan untuk menilai solusi terbaik yang diinginkan. 


\section{Website}

Marisa (2017) menyatakan bahwa kumpulan animasi baik berupa teks, suara, gambar, gif atau bahkan program multimedia yang dikumpulkan pada suatu halaman dan dipublish yang bersifat statis maupun dinamis disebut website. Biasanya antar halaman memiliki hubungan yang disebut sebagai hyperlink. Pendapat lain mengatakan bahwa halaman sebuah situs yang memiliki informasi data yang valid dan ditampilkan secara visual berbasis browser disebut website Abdulloh (2017).

\section{METODELOGI PENELITIAN}

Dalam penelitian ini penulis harus melalui tahapan dalam mendapatkan sebuah data yang dijadikan objek penelitian guna mendapatkan solusi dari permasalahan yang akan diangkat dalam penelitian ini adapun alur rancangan penelitian sebagai berikut :

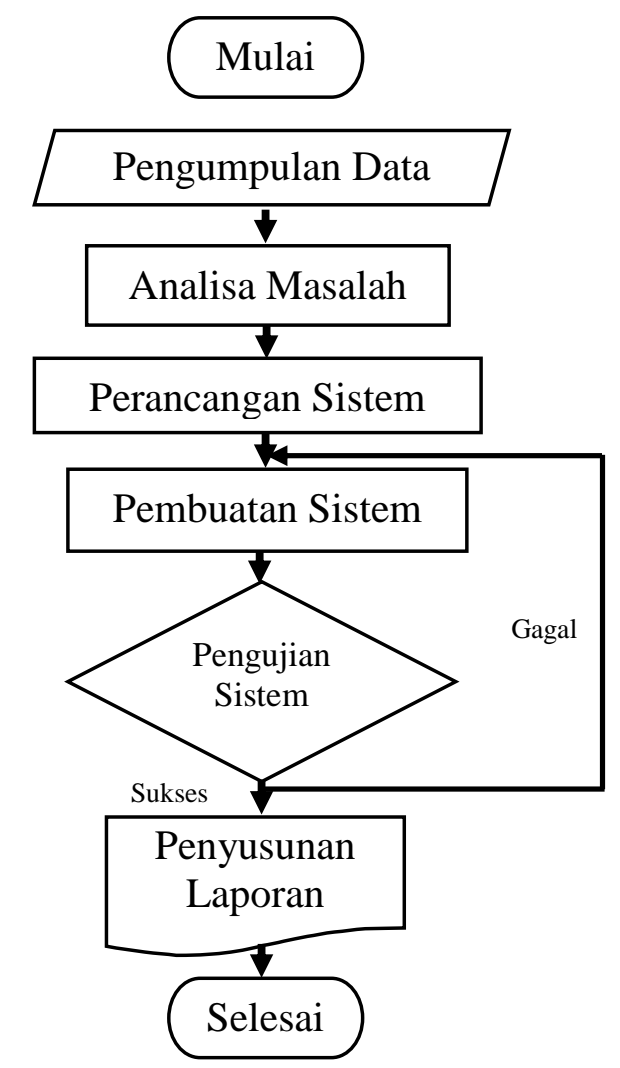

Gambar 1 Rancangan Penelitian Sistem Pendukung Keputusan
HASIL PENELITIAN DAN PEMBAHASAN

A. Perancangan

1. DFD Level 0

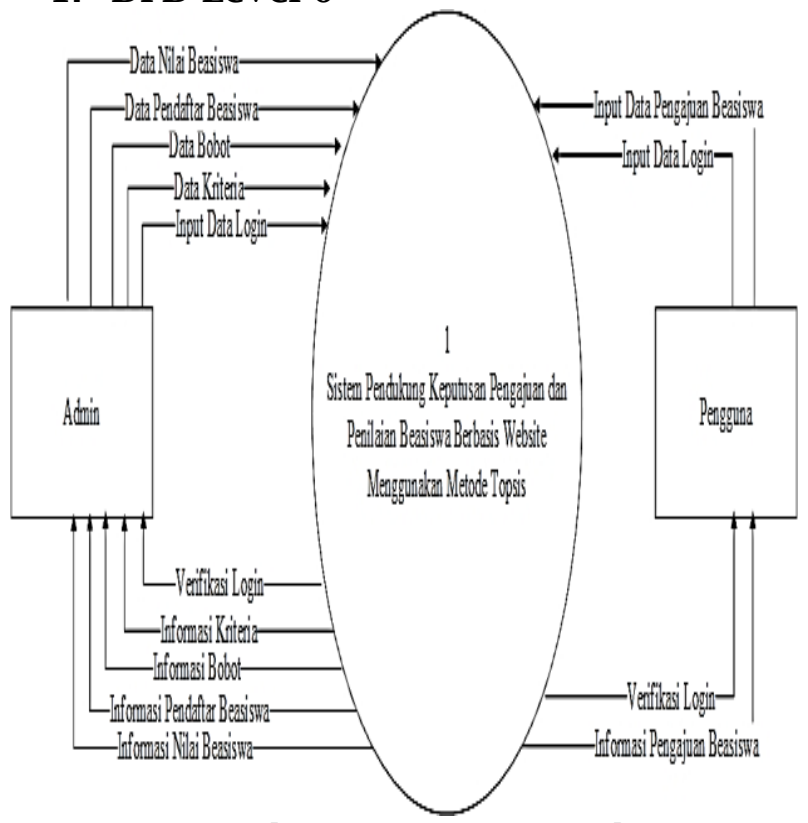

Gambar 2 Diagram Level 0

\section{DFD Level 1}

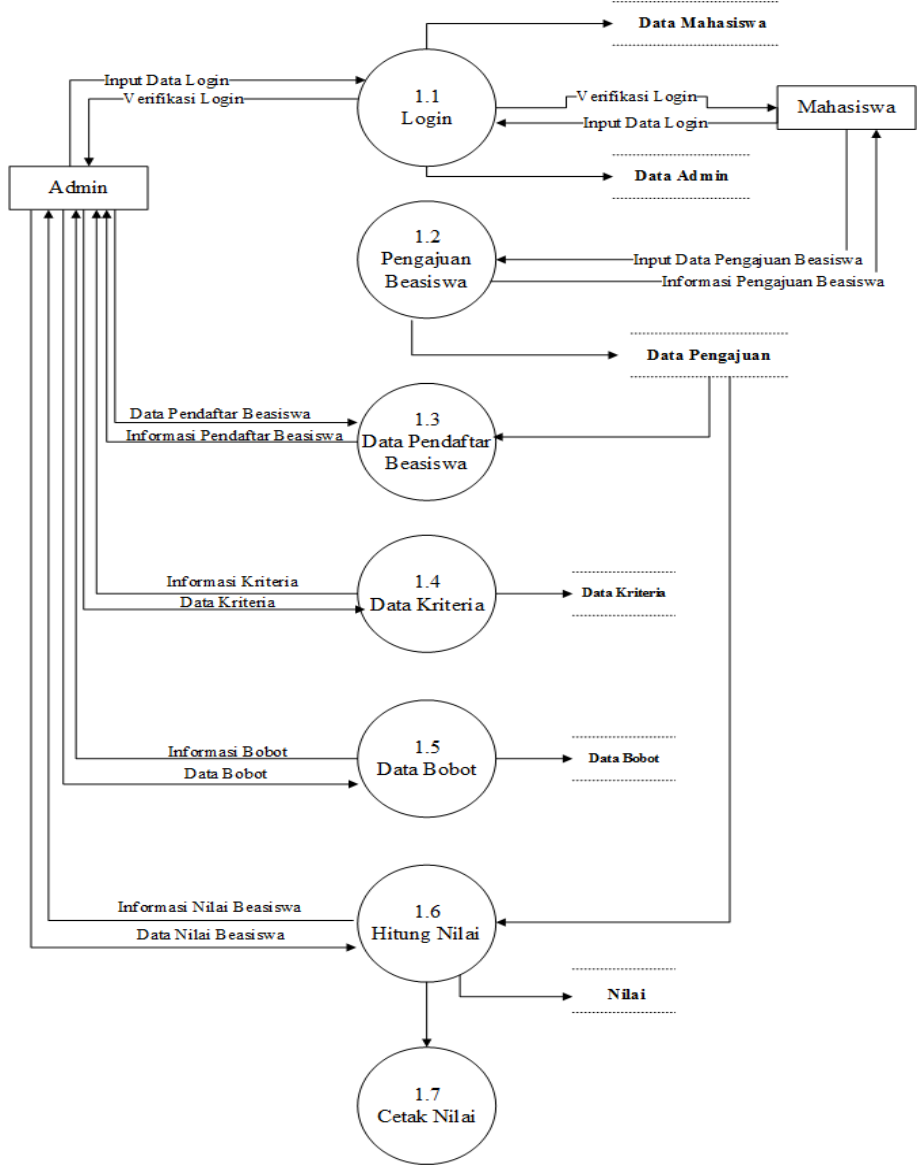

Gambar 3 Diagram Level 1 
3. Metode TOPSIS

Dalam penghitungan menggunakan metode TOPSIS ini penghitung didasarkan kriteriakriteria dan bobot sebagai berikut :

Tabel 1 Nilai Kriteria dan Bobot

\begin{tabular}{|c|c|c|c|c|c|}
\hline \multirow{2}{*}{ No. } & \multirow{2}{*}{ Bobot } & \multirow{2}{*}{ Kriteria } & \multirow{2}{*}{ Rentang } & \multicolumn{2}{|c|}{ Nilai } \\
\hline & & & & PPA & BBM \\
\hline \multirow{5}{*}{1.} & \multirow{5}{*}{4} & \multirow{5}{*}{$\begin{array}{l}\text { C1 } \\
\text { IPK }\end{array}$} & $>3,51$ & 8 & 6 \\
\hline & & & 3,25 s.d 3,50 & 6 & 4 \\
\hline & & & 3,00 s.d 3,24 & 4 & 3 \\
\hline & & & 2,75 s.d 2,99 & 3 & 2 \\
\hline & & & 2,50 s.d 2.74 & 2 & 1 \\
\hline \multirow{4}{*}{2.} & \multirow{4}{*}{3} & \multirow{4}{*}{$\begin{array}{c}\text { C2 } \\
\text { Pekerjaan }\end{array}$} & Almarhum (yatim) & 4 & 4 \\
\hline & & & Tani/buruh/pensiunan & 3 & 3 \\
\hline & & & PNS/TNI/Polri & 2 & 2 \\
\hline & & & Wiraswasta & 1 & 1 \\
\hline \multirow{4}{*}{3.} & \multirow{4}{*}{3} & \multirow{4}{*}{$\begin{array}{l}\text { C3 } \\
\text { Gaji }\end{array}$} & $<500.000$ & 4 & 8 \\
\hline & & & $500.001-1000.000$ & 3 & 4 \\
\hline & & & $1.000 .001-1.750 .000$ & 2 & 3 \\
\hline & & & $>1.750 .000$ & 1 & 1 \\
\hline \multirow{3}{*}{4.} & \multirow{3}{*}{4} & \multirow{3}{*}{$\begin{array}{c}\text { C4 } \\
\text { Orgamawa }\end{array}$} & $>7$ kegiatan & 4 & 4 \\
\hline & & & 4-6 kegiatan & 2 & 2 \\
\hline & & & 1-3 kegiatan & 1 & 1 \\
\hline \multirow{4}{*}{5.} & \multirow{4}{*}{3} & \multirow{4}{*}{$\begin{array}{c}\text { C5 } \\
\text { Tanggungan }\end{array}$} & $>=4$ anak & 5 & 5 \\
\hline & & & 3 anak & 3 & 3 \\
\hline & & & 2 anak & 2 & 2 \\
\hline & & & 1 anak & 1 & 1 \\
\hline \multirow{3}{*}{6.} & \multirow{3}{*}{5} & \multirow{3}{*}{$\begin{array}{c}\text { C6 } \\
\text { Pengurus }\end{array}$} & Ketua & 4 & 4 \\
\hline & & & Sekretaris/Bendahara & 2 & 2 \\
\hline & & & Pengurus lainnya & 1 & 1 \\
\hline
\end{tabular}

Pada sistem yang akan dibuat penghitungan nilai mengguna algoritma fuzzy topsis adapun langkah dalam pengolahan melalui beberapa tahap sebagai berikut :

1) Membuat matriks keputusan yang ternormalisasi.

Rumus :

$$
r_{i j}=\frac{x_{i j}}{\sqrt{\sum_{i=1}^{m} x_{i j}^{2}}}
$$

2) Membuat matriks keputusan yang ternormalisasi terbobot Rumus :

$$
y_{i j}=w_{i} r_{i j}
$$

3) Menentukan matriks solusi ideal positif dan matriks solusi ideal negatif

Rumus :

$$
\begin{aligned}
& A^{+}=y_{I}^{+}, y_{2}^{+}, \ldots ., y_{n}^{+} \\
& A^{-}=y_{1}^{-}, y_{2}^{-}, \ldots, y_{n}^{-}
\end{aligned}
$$

$\mathrm{A}+=$ Solusi ideal positif

$\mathrm{A}^{-}=$Solusi ideal negative

4) Menentukan jarak antara nilai setiap alternatif dengan matriks solusi ideal positif dan matriks solusi ideal negatif Rumus :

$$
D_{i}^{+}=\sqrt{\sum_{j=1}^{n}\left(y_{i}^{+}-y_{i j}\right)^{2}}
$$


dan

$D_{i}^{-}=\sqrt{\sum_{j=1}^{n}\left(y_{i j}-y_{i}^{+}\right)^{2}}$

5) Menentukan nilai preferensi untuk setiap alternatif.

Rumus :

$$
V_{i}=\frac{D_{i}^{-}}{D_{i}^{-}+D_{i}^{+}}
$$

\section{B. Pembahasan}

\section{Tampilan Antar Muka Mahasiswa}

a. Tampilan Login

Sistem ini mengaharuskan penggunaanya harus login terlebih dahulu

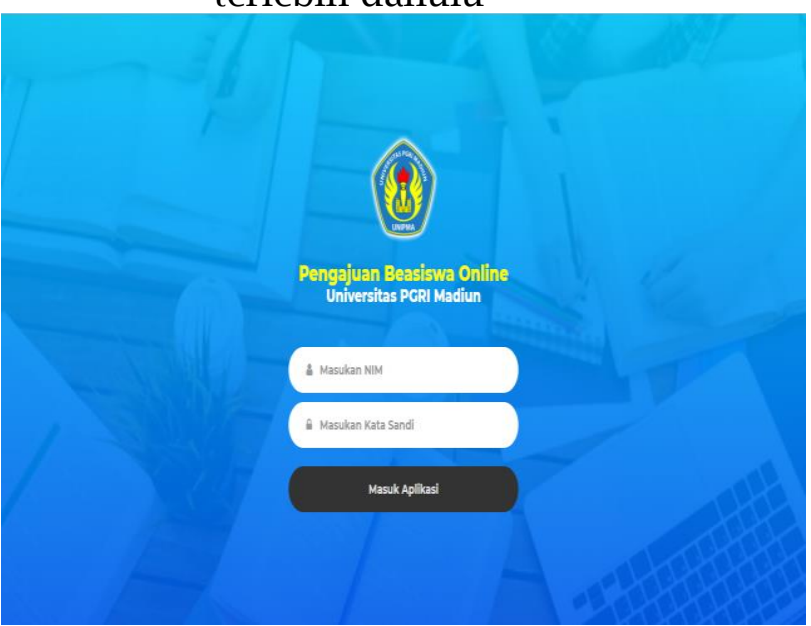

Gambar 4 Tampilan Login

Mahasiswa

b. Pilih Jenis Beasiswa

Mahasiswa kemudian memilih

jenis beasiswa yang akan diajukan

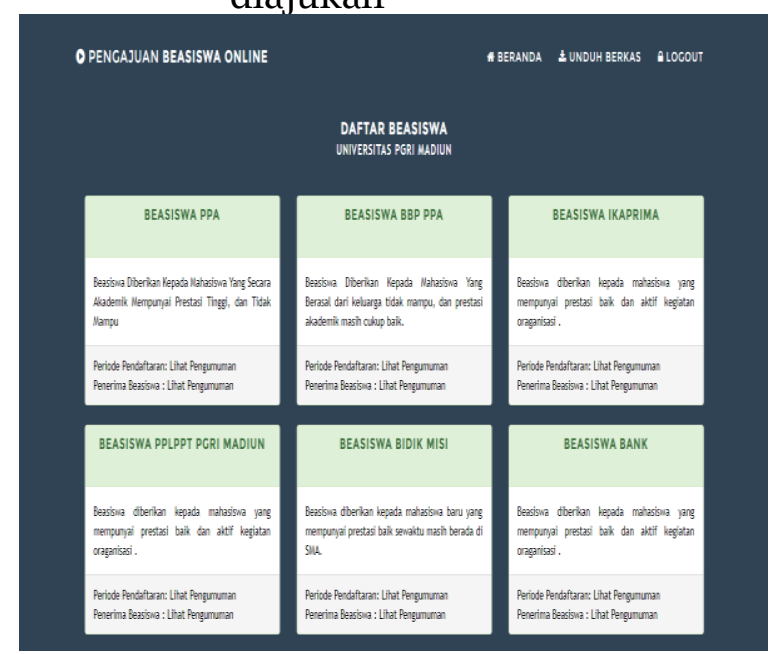

Gambar 3.2 Tampilan Pilh Jenis Beasiswa

c. Pengajuan Berkas

Mahasiswa akan mengajukan berkas beasiswa

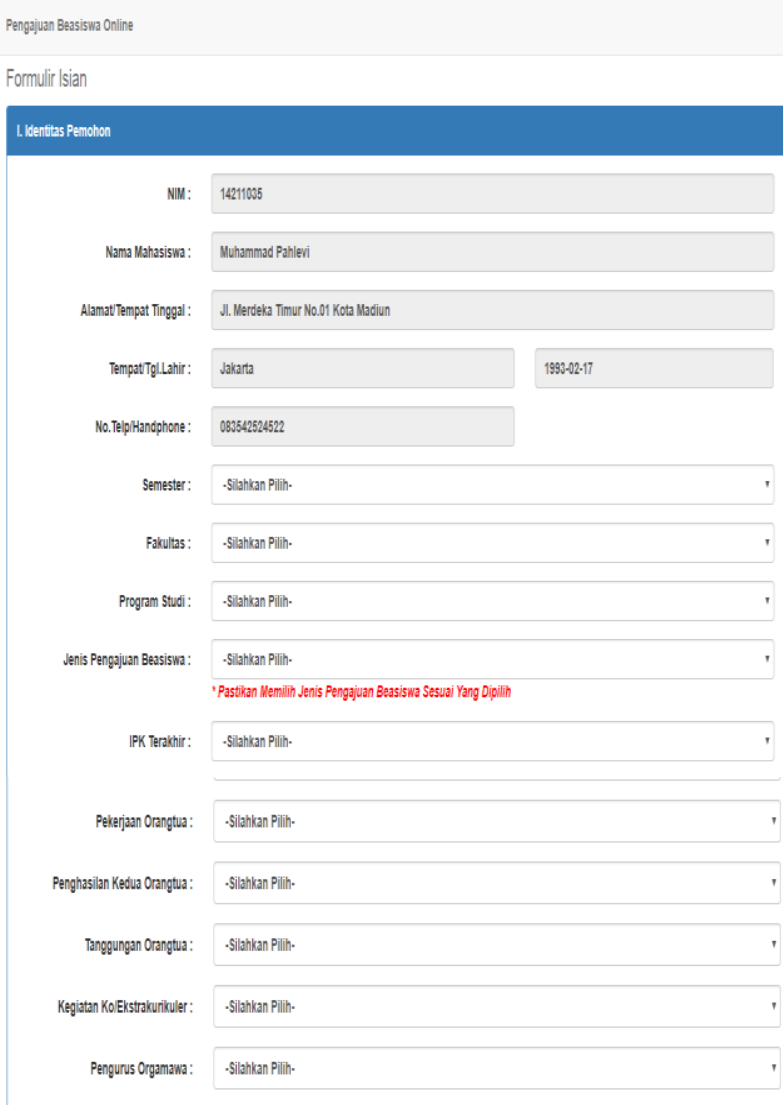

Upload File

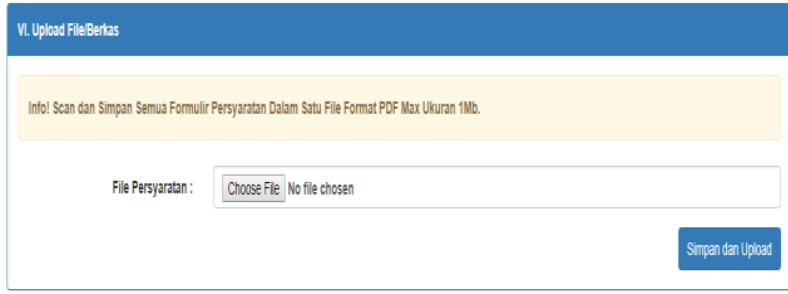

Gambar 5 Tampilan Pengajuan Berkas

\section{Tampilan Anatar Muka Admin}

a. Tampilan Login

Sebelum bisa masuk ke sistem admin harus login 


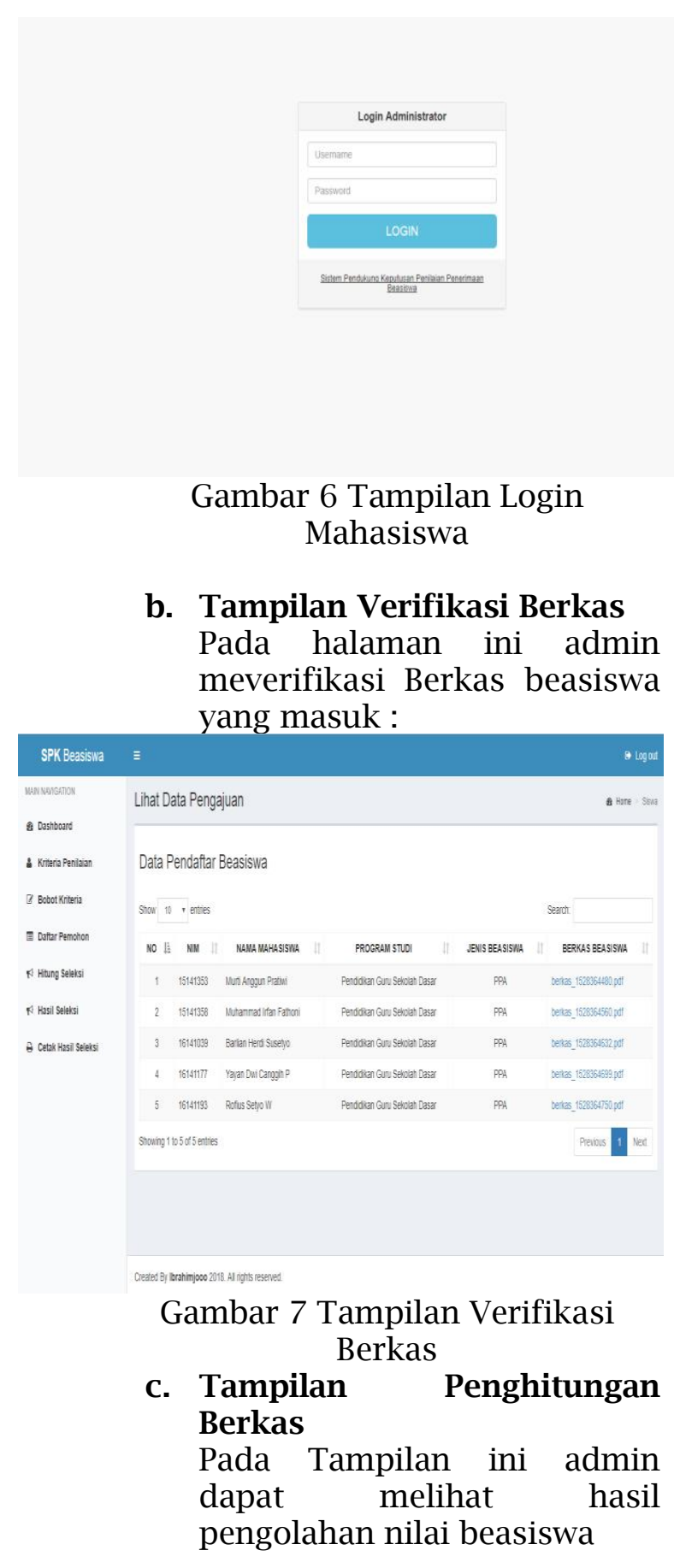

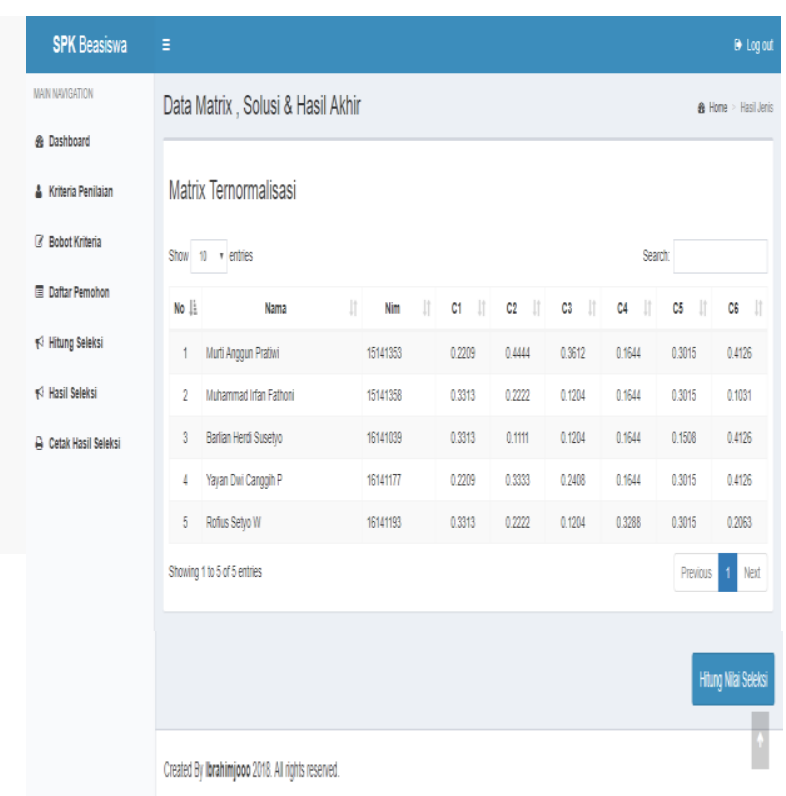

Gambar 8 Tampilan Hitung

\section{d. Tampilan Cetak}

Pada tampilan ini hasil akhir sistem adalah dapat melihat penerima beasiswa dengan kuota setiap prodi :

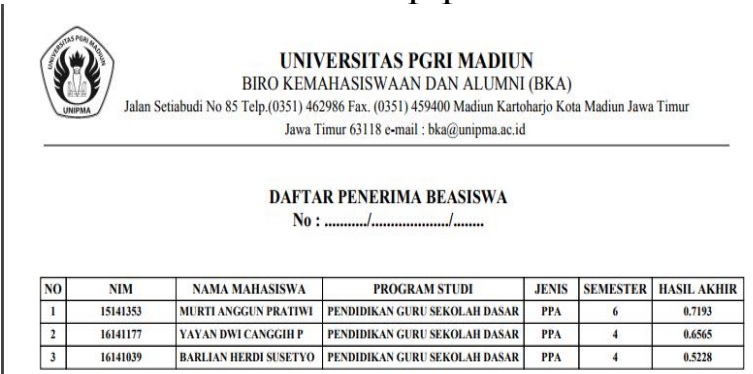

Gambar 7 Tampilan Verifikasi Berkas

Tampilan Penghitungan
Berkas
Pada Tampilan ini admin
dapat melihat hasil
pengolahan nilai beasiswa


metode TOPSIS sangat layak digunakan di untuk membantu dan mempermudah dalam pengolahan nilai beasiswa pada BKA Universitas PGRI Madiun.

\section{Pembahasan}

Sistem penghitungan yang akan dibuat menggunakan metode TOPSIS di mana nilai setiap nilai kriteria dikalikan dengan bobot kriteria yang telah ditentukan. Setiap kriteria memiliki bobot nilai sesuai jenis beasiswa yang ditentukan. Hal ini berbeda dengan pengolahan nilai sebelumnya. Harapan dengan sistem ini adalah dapat mempermudah dalam menentukan penerima beasiswa.

\section{KESIMPULAN}

Berdasarkan hasil penelitian yang dijalankan maka dapat diambil kesimpulan bahwa dengan adanya sistem pendukung keputusan dan penilaian beasiswa mahasiswa sebagai pengguna dan Biro Kemahasiswaan dan Alumni sebagai administrator dapat mengajukan dan mengolah nilai beasiswa dengan mudah karena sistem ini menggunakan penghitungan metode TOPSIS di mana metode ini dapat mengelola nilai beasiswa dengan banyak kriteria serta bobot berbeda.

\section{DAFTAR PUSTAKA}

Abdulloh. 2016. Easy \& Simple Web Programming, Jakarta: PT. Elex Media Komputindo.
Arbiyan 2017. "Sistem Pendukung Keputusan (SPK) Pemberian Beasiswa Berbasis TOPSIS (Studi Kasus Yayasan Pendidikan AlHikmah Malang," Jurnal Ilmiah Teknologi dan Informasi ASIS (JITIKA), vol. 11, p. 2

Herawatie dan E. Wuryanto. 2017. "Sistem Pendukung Keputusan Pemilihan Mahasiswa Berprestasi dengan Metode Fuzzy TOPSIS," Jurnal of Information Systems Engineering and Bussines Intelligence, vol. 2, no. 2, pp. 92-100.

Marisa. 2017. Web Programming (Client Side And Server Side), Yogyakarta: Deepublish, 2017.

Mujilahwati. 2014. "Diagnosa Penyakit Tanaman Hias Menggunakan Metode Certainty Factor Berbasis Web," Jurnal TeknikA, vol. 6, p. 586, 2014.

Nofriansyah dan S. Defit. 2017. Multi Criteria Decision Making (MCDM) pada Sistem Pendukung Keputusan, Yogyakarta: Deepublish, 2017.

Sari, Febrina. 2018. Metode dalam Pengambilan Keputusan, Yogyakarta: Deepublish, 2018

Wijayanti dan A. Fadlil. 2014. "Sistem Pakar Mendiangnisa Jenis Penyakit Stroke Menggunakan Metode Certainty Factor," Jurnal Sarjana Teknik Informatika, vol. 2, p. 692 